ISSN: 0210-7287

DOI: http://dx.doi.org/10.14201/161620199197215

\title{
UNHA APROXIMACIÓN ECOCRÍTICA Á OBRA DE CASTELAO
}

\section{An Ecocritical Approach to Castelao's Work}

\author{
Raúl COSTAS PEREIRA \\ Universidade de Santiago de Compostela/Centro Ramón Piñeiro \\ para a Investigación en Humanidades \\ RaulCostas@Live.com
}

Recibido: junio de 2019; Aceptado: septiembre de 2019; Publicado: diciembre de 2019

Ref. Bibl. RAÚl COSTAS PEREIRA. UNHA APROXIMACIÓN ECOCRÍTICA Á

OBRA DE CASTELAO. 1616: Anuario de Literatura Comparada, 9 (2019), 197-215

RESUMO: Esta lectura de breves fragmentos da obra de Alfonso Daniel Castelao tratará de amosar a rendibilidade dunha revisión ecocrítica da súa produción artístico-literaria. Partido de elementos básicos cunha presenza practicamente transversal na súa obra tentarase denotar a visión do autor no referente á natura e ó medio ambiente. Por unha parte, os elementos que se terán en conta pra tratar de achegar unha lectura alternativa da súa obra serán a figura do árbore, encadrado dentro da paisaxe, e da vaca, dentro do campo de análise dos Estudos Animais. Pola outra, tentarase de achegar información sobre a perspectiva artística do autor así como comparar a presenza dos devanditos elementos no resto das súas obras. Como obxectivo final, tentarase destacar a vertente ecocrítica do autor a través do seu legado.

Palabras clave: ecocrítica; Castelao; paisaxe; estudos animais.

ABSTRACT: In this study I will be analyzing brief passages of Alfonso Daniel Castelao's work in order to show the profitability of an ecocritic revision of his 
artistic and literary production. Starting from basic elements with a transverse presence in his work, I will try to denote the author's vision in terms of nature and environment. The elements that I am taking into account to try to provide an alternative reading of his work will be the figures of the tree from a landscapeoriented perspective and the cow as seen from animal studies. Furthermore, I will try to offer information about the artistic perspective of the author and then compare the presences of the already mentioned elements in the rest of his works. Finally, I will try to highlight the author's ecocritic aspect through his legacy.

Key words: Ecocriticism; Castelao; Landscape; Animal Studies.

Val máis unha Terra con albres nos montes que un Estado con ouro nos bancos (Castelao, Sempre en Galiza)

\section{INTRODUCIÓN}

A ecocrítica desvélase coma un enfoque de análise de gran rendibilidade, ademais de resultar acorde ás inquedanzas sociais que atravesan, prominentemente, as sociedades occidentais, nas que o factor ecolóxico se converte nun punto central en multitude de axendas políticas, tanto por parte de activistas e partidos en prol da concienciación e que avogan por unha mudanza no referente á relación humana co medio ambiente; como por parte dos detractores que negan as evidencias resultantes do cambio climático ou da contaminación dos océanos. Non obstante, resulta interesante, dende o punto de vista didáctico, ver como unha das figuras máis sobranceiras dentro do sistema cultural e literario do seu tempo, ademais de exercer un labor referente no eido da política, interpreta o factor natural na súa obra artístico literaria. A produción de Alfonso Daniel Rodríguez Castelao resulta triplamente interesante ó acceder a ela dende unha perspectiva ecocrítica. En primeiro lugar, Castelao é unha figura cunha vertente política e social fortemente marcada, símbolo do galeguismo por antonomasia ademais dun activista exiliado polas súas reivindicacións, mais escasamente interpretada dende unha perspectiva ecocrítica. En segundo lugar, a figura de Castelao reflicte ó artista total, que destaca dentro de tódalas súas prácticas artísticas, dende a pintura e o debuxo ata a narrativa maila dramaturxia pasando polo ensaio mailo discurso político. Tanto é así que o único xénero do que non deixou evidencias materiais foi dunha creación lírica, alén dos versos de Leliña na obra Os vellos non deben namorarse. En terceiro lugar, pola cantidade 
de elementos susceptibles de seren interpretados dende unha perspectiva ecocrítica, pois en tódolos xéneros cultivados achegará unha posición que, dende a actualidade, podería ser vencellada a un pensamento ecoloxista, o cal resulta vangardista na coetaniedade propia ó autor.

A tríade de factores que denotan e suscitan interese pra a interpretación dun Castelao so dunha óptica ecocrítica coinciden e concílianse coas posibilidades que achega a propia perspectiva, como é unha interpretación da obra como produto artístico que cumpre un labor didáctico e propagandístico a nivel ideolóxico no referente á dimensión social, nomeada no primeiro punto. A capacidade de adoptar unha perspectiva comparativa interartística dende un prisma ecocrítico permite evidenciar como tódalas producións de Castelao se relacionan entre si a nivel temático e formal e como sustentan un discurso, susceptible de ser considerado como ecocrítico. Sumado a estes dous factores cabe nomear a dobre vertente do autor, pois afondará na relación do humano co medio ambiente, mais tamén a consideración deste do mundo animal e as implicacións da relación que existe entre ámbalas especies. Isto permite afondar na súa obra dende dúas ramas da ecocrítica, tanto dende a perspectiva centrada no medio como unha que afonde coa relación e consideración dos animais, característica dos Animal Studies. A repetición de motivos ó longo da súa produción permite pór en contraste elementos recorrentes e interpretar como Castelao creaba a e asociaba elementos dun imaxinario popular, que tentará sublimar coa súa práctica artística e literaria.

\section{RENDIBILIDADE PRAGMÁTICA DA ECOCRÍTICA}

A ecocrítica achega múltiples posibilidades no caso de analizar a este autor en concreto, pois as pólas que agroman da súa obra dende este tipo de análise serán diversas. Xa se comentou a súa capacidade polifacética. Resulta pertinente rememorar a semántica contida dentro do propio nome da vertente teórica en cuestión e prover unha explicación etimolóxica das dúas palabras que compoñen o termo que dá nome á disciplina. Dunha beira, cóntase co prefixo eco-, que ten a súa orixe no substantivo do grego clásico oíxos. Decote, a acepción que se selecciona pra a súa tradución é a de casa; emporiso, a palabra conta con outros matices léxicos ós que cómpre atender pra percibir de xeito diáfano cal é o seu rol dentro do termo que delimita a disciplina. A acepción do substantivo oícos contempla significados tales como 'patria' ou 'fogar', onde o significado pasa a ser máis inocuo e metafórico ó referirse a unha noción abstracta e inmaterial. 
Doutra beira, tópase o termo crítica, intimamente ligado á dimensión literaria; non obstante, a súa etimoloxía volve a remitir ó grego clásico, кpívw, vocábulo que no dicionario consultado é traducido como choose ou to pick out, que se podería entender como 'seleccionar' ou 'escoller'. O radical da palabra en cuestión tamén está presente no termo xpícı, relacionado directamente co power of distinguishing e mesmo con significados como decision e judgment; véxase aquí o "poder de distinción", a "decisión" e o "xuízo" que carrexa calquera disciplina que introduza o vocábulo «crítica" no termo que a define. A vertente da disciplina á hora de analizar un fenómeno determinado, no caso da ecocrítica unha relación entre seres que cohabitan nun medio, e tratar de esclarecer o seu funcionamento a través do representado no texto. Nun primeiro momento da súa dimensión máis intrínseca e evidente, non obstante, a contemplación do fenómeno pode inferir razoamentos nun nivel de carácter extrínseco, doadamente proxectable do texto ou do seu contido.

A ecocrítica agroma como unha disciplina que renega do antropocentrismo, deixa fóra da súa criba, da súa análise, a figura humana en canto elemento central e referencial da investigación. Porén, o papel do humano si pode ser contemplado dende a perspectiva dun ente biolóxico máis que se relaciona cun hábitat dunha forma característica, a cal é, adoito, a máis prexudicial de entre tódolos seres vivos ou catástrofes naturais.

Pra deitar luz sobre a definición da disciplina véxanse as seguintes citas: "The study of the relationship between literature and the physical environment [taking] an earth-centered approach to literary studies" (Glotfelty 1996: xviii). Nesta primeira definición dos estudos ecocríticos o factor humano nin sequera aparece nomeado; pola contra, percíbase a presenza do «enfoque centrado na terra" no que Cheryll Glotfelty pon énfase. Sen dúbida, esta definición concorda coa devandita aproximación achegada nesta introdución; quizabes podería denominarse unha visión "cosmocéntrica» en oposición á visión antropocéntrica da que se opón á ecocrítica. Non obstante, óllese a seguinte cita: «Relationship between literature and environment conducted in a spirit of commitment to environmental praxis» (Buell 1995: 430). Na definición de Lawrence Buell podemos atopar o compoñente humano a través do factor activista que pode representar a ecocrítica. Ámbalas dúas definicións abraian por mor da súa sinxeleza en contraposición coa definición da meirande parte de disciplinas dos estudos literarios. A pouca concreción da definición vai ligada ó seu carácter interdisciplinario xa nomeado, pois o sucinto e sinxelo da definición non acoutan o seu marco teórico-metodolóxico. Unha característica de suma utilidade no caso da obra de Castelao, por mor do seu carácter poliédrico e por mor do contido ecocrítico que contén no seu interior e, inclusive, na súa forma. 


\section{CASTELAO, AUTOR TOTAL}

Castelao foi un autor polígrafo, pois malia que sempre conservou un estilo simple o efecto da súa prosa contrasta coa forma de expresión pois será capaz de obter unha gran rendibilidade a través de enunciados sinxelos ao longo de toda a súa tipoloxía textual. A esta vontade de intelixibilidade e sinxeleza cómpre sumar a visión artística do autor, que se suma á súa vertente social, tamén expresada na súa actividade política e cultural alén dos lindeiros da creación. O autor coidaba que a paisaxe, amais de ser obxecto central dalgunhas das súas obras, era un elemento conformador da concepción artística dun autor, unha forza que infunde un carácter idiosincrático á arte que, no seu caso, asocia á galeguidade. Así o expresa na súa palestra de Arte e galeguismo o propio Castelao (2000, 4: 144):

De maneira que son sentimentos ou emocións o que eispresa o artista ¿E quen lle dá ós homes os sentimentos que teñen? Polas miñas contas, en non perdendo o tempo con razós centíficas que atoparíamos de camiño, a terra ou mellor dito o paisaxe é quen vai traballando, pouco a pouco, os sentimentos dos homes, a terra é a que dá persoalidade. A razón de que o Arte galego dea máis emoción ós galegos que ós alleos non pode sere máis que a de xuntar mellor a maneira de aitividade do artista galego coa dos demais galegos, pois todos nós temos no sentimento, que é fillo da terra, os mesmos matices.

A literatura, canda a pintura e a música, non foxe desta concepción artística, pois tamén é contemplada como xeito de expresión da galeguidade que a súa vez tamén é asociado coa terra e coa natura. Véxase, deseguido, outras palabras do autor rianxeiro, na mesma palestra, referíndose a este xeito de comprender a arte: "O arte é un, e a literatura, coma a música e a pintura galega, non poden sere máis que xeitos de eispresión dunha mesma beleza; a da nosa terra. E sendo eu un dos que traballan polo conquerimento dun arte galego, teño que defender a fala dos nosos avós» (Castelao 2000, 4: 134). Nesta afirmación, ademais, asocia a reivindicación dunha arte propia expresada a través da "fala dos nosos avós", outro compoñente fundamental na súa concepción identitaria no referente ó produto artístico. Castelao constata a importancia que ten a natura na súa obra cando enuncia o seguinte: "Eu non sei pintar, nin quero saber pintar; mais sinto o noso paisaxe e podo decirvos que o pouco que valo débollo a estar deitado nos piñales, deixando que a Natureza entrase dentro de min» (Castelao 2000, 4: 147). Esta confesión metafórica do autor achéganos a estreita vinculación que busca, alomenos expresar, coa natura. A interpretación artística de Castelao pasa obrigatoriamente polo factor identitario que confire 
o seu entorno, Galiza, que pra o autor ten unha indisoluble relación coa característica coa natureza que configura o territorio e, á súa vez, os hábitos dunha sociedade idiosincrática. Unha relación que autor criticará en moitas ocasións, facendo fincapé na necesidade do establecemento dunha relación de carácter simbiótico ademais dun coidado e dunha consideración da natureza moitas veces esquecida. O tratamento da natura na obra Castelao é múltiple e abondosa, pois non só abranguerá multitude de motivos senón que as súas aparicións serán constantes e abondosas en tódalas artes practicadas polo autor.

\section{A PAISAXE: AS ÁRBORES}

Un elemento frutífero no referente á análise ecocrítica é a propia paisaxe, pois este elemento conformando xeralmente pola natura, ou sobor desta, achega multitude de reflexións que poden pór énfase na relación que mantén o humano co medio que habita. A noción de paisaxe natural resulta sumamente ampla; porén, no caso da obra de Castelao a asociación desta coa vexetación é frecuente, mais cando se pensa na paisaxe propia da Galiza, a que o autor tentará plasmar nos seus textos e nas súas pinturas, non queda ningunha dúbida de que se trata da paisaxe determinada e prototípica. Acotío pasa por unha paraxe de vexetación frondosa, probablemente acompañada por un océano no horizonte, onde a presenza da dimensión humana fica en multitude de ocasións relegada a un segundo plano. Emporiso, a paisaxe mudará fondamente segundo o momento no que esta sexa contemplada, o tempo é un factor determinante na concepción dunha paisaxe ligada á natura, xa que o resultado da observación está fortemente condicionado polo intre no que se observe un fenómeno na meirande parte da tipoloxía paisaxística:

O método para o entendemento da Paisaxe ten de supor u senso e vivencia primeira do tempo. Isto para moitas xentes significa un esforzo e traballo. Como que non son poucas as xentes fuxitivas do tempo das rúas e das cidades para repousar na paisaxe imaxinada fóra do tempo, ou soamente rexida polo tempo cósmico. Coa nosa tese non se mingua a valencia da paisaxe como repouso (Otero Pedrayo 1955: 116).

A identificación de Ramón Otero Pedrayo semella remitir ó locus amoenus, referíndose a el como espazo de descanso fóra do tempo; porén, entende a paisaxe como proceso, ligada ó devir. Pódese identificar esta visión da paisaxe como un proceso vivo, no cal se contempla a evolución, un dinamismo continuo, a través de "procesos e formas» que cómpre separar e 
delimitar pra, posteriormente, volver a reinterpretar na paisaxe a través da suma do conxunto de elementos que a compoñen e das relacións diádicas que manteñen estes entre si:

A paisaxe componse de procesos e formas. Só a análise os pode distinguir, e é precisión de métodos e de viviencia das cousas separalos, a condición de xuntalos seguida novamente no devalar. Cecais non pareza a palabra ben axeitada. Ten devalar o seu significado. Pero sendo fermosa palabra, chea de luz no tempo, dona da intuición das cousas xurdindo e sucedéndose no tempo, xulgámola a mellor para abranguer esta maneira de se manifestar a forma como fito no proceso e o proceso como memoria, ás veces aínda impaciente e choutadora, na forma (Otero Pedrayo 1955: 116).

Partindo desta reflexión de Otero pódese chegar á conclusión de que as formas, supeditadas ó devir dun proceso, constitúense sobre determinados elementos conformadores da paisaxe como é o caso da vexetación ou o mar. A vexetación, pois, é un elemento que dá forma á paisaxe, condicionada polo "devalar", presente no paso das estacións, mais tamén nas distintas estadías polas que pasa unha árbore, unha planta ou unha flor. Non obstante, o devalar vai alén destas mudanzas, vagarosas, mais perceptibles pra o humano; a formación de montañas, cordilleiras e continentes tamén son procesos que se desenvolven de xeito máis demorado malia que constante. Porén, a flora será o elemento máis destacable e perceptible da paisaxe galega por mor do cambio que amosa no devalar, dende unha perspectiva humana, e que resulta perceptible á contemplación.

No referente ás árbores dentro da obra de Castelao, a súa presenza é pingüe e constantemente recorrida. Véxase ó respecto unha pasaxe sumamente reveladora do Sempre en Galiza. No fragmento en cuestión Castelao escribe sobre a árbore, da súa concepción e a significación que el lle outorga. Partindo da figura arbórea establecerá unha serie de relacións coa terra, Galiza, asemade que medita sobre o papel da árbore na vida humana a través dunha serie de sentencias curtas que conformarán o texto, no cal a "albre» será o punto de partida pra tódalas consideracións do autor:

O albre

O albre é o símbolo do señorío espiritual de Galiza.

O albre é un engado dos ollos, pola súa fremosura; é unha ledicia dos ouvidos, porque nel cantan os paxaros; é un arrolador do esprito, porque nas súas ponlas conta contos o vento. 
O albre dános a froita, que é un manxar composto polo mesmo Creador, para regalía do noso paladar: o derradeiro ben que quedou do Paradiso perdido.

O albre pídelle auga ao ceo para que a terra teña sangue, vida e bonitura.

O albre danos a sobre fresca no vran e a quentura garimosa no inverno.

O albre daános as trabes, o sobrado e as portas da casa. Dános a cama, o almario das sabáns e a artesa do pa. Dános o berce, o báculo da vellez e caixa para baixar á terra.

O albre dános o papel barato que nos trai a decotío as novas do que pasa no mundo.

Val máis unha Terra con albres nos montes que un Estado con ouro nos Bancos.

A calvicie dos montes galegos é unha terrible acusación contra o Estado unitario.

Os albres son as minas galegas que nós saberemos esplotar cando a nosa Terra sexa nosa.

A repoboación forestal será o patrimonio da nación galega e o mellor aforro da colectividade.

$\mathrm{Na}$ nosa Terra danse os mellores albres.

O dia que seipamos o que val un albre, aquel día non teremos necesidade de emigrar (Castelao 2000, 2: 190).

O texto constitúese mediante unha marcada anáfora que se repite ó longo case tódolos parágrafos do fragmento. Esta anáfora, principiada polas palabras "O albre», será o concepto darredor do que orbite unha serie de reflexións de carácter social, político mais tamén ecolóxico. Comeza aludindo ó "símbolo do señorío espiritual da Galiza»; é probable que esta metáfora faga referencia ó himno da Galiza ${ }^{1}$, Os pinos de Eduardo Pondal, establecendo unha relación entre espírito, natura e patria.

1. O mesmo Castelao, no texto "A nación galega, a súa bandeira, o seu himno e os seus mortos ilustres» (2000, 3: 101), afirma o seguinte: «Iste himno foi titulado pol-o seu autor Os pinos, porque n-il os piñeiros representan os nosos antepasados que chaman por nós pra que defendamos a nosa Patria, a Patria galega». 
Continúa elaborando o texto apoiándose na anáfora, identificando a árbore como o alimento dos sentidos e do espírito. O "engado dos ollos", "ledicia dos ouvidos", "arrolador do esprito" e "regalía do paladar", o árbore achega todos estes estímulos; porén, véxase a antedita relación diádica entre a árbore mailo humano, co paxaro ou co vento respectivamente. $\mathrm{O}$ texto tamén desvela unha preocupación sobre a propia figura da árbore no devalar da vida. Cando Castelao afirma "Dános o berce, o báculo da vellez e a caixa para baixar á terra», está desvelándoo como un elemento presente ó longo da vida dunha persoa e en comuñón con ela. Será a árbore convertida en madeira, quen a arrole, quen a manteña en pé cando lle fallen as forzas e quen o acompañe alén da morte. Este pensamento adquire unha meirande transcendencia cando o obxecto sobre o que elabora o discurso é "O albre", e non a persoa. O cambio da perspectiva, partindo da árbore, da natura, pra chegar ó humano afasta ó texto dunha visión antropocéntrica. Non obstante, Castelao semella consciente de que a árbore tamén é alicerce da cultura cando se refire a que é o papel que trae as novas do mundo. Deseguido, o texto achega a frase «Val máis unha Terra con albres nos montes que un Estado con ouro nos Bancos». Nela, créase unha dobre oposición; por unha parte, reflíctese o binomio terra/estado, por outra, achégase a dicotomía árbores/ouro. Partindo destas oposicións marcadas polo autor pódense inferir outras, tamén presentes ó longo da súa obra, como son rural/urbano. A posición asumida polo autor no enunciado podería ser interpretada a día de hoxe como unha postura decrecentista e profundamente ecoloxista, máis aínda cando, a seguir, equipara a repoboación forestal ó patrimonio da nación galega. Pra rematar, Castelao asume na frase final o descoñecemento do valor dunha árbore; esta cuestión, simple a priori, adquire unha gran fondura despois da serie de reflexións que expón.

Asemade, en multitude de pinturas do autor pódense atopar imaxes inzadas de árbores, xeralmente piñeiros, que representan a querenza pola natura do autor mailo seu apego pola paisaxe autóctona. Ademais, a presenza de árbores e vexetación chega a mesturarse con outros elementos naturais característicos da orografía galega e da súa obra pictórica como é propio mar. A preferencia de Castelao na dimensión paisaxística céntrase xeralmente na natura e se tivera que prestar atención a un modus vivendi determinado porá sempre énfase no tipo de vida rural, máis apegado á natura. Resulta interesante no caso exposto como a teoría de Otero Pedrayo sobre a interpretación da paisaxe casa perfectamente coa produción artística do autor rianxeiro e permite facer unha lectura da súa obra nesta clave, poñendo en comuñón a visión da que era capaz un erudito xeógrafo como Otero e a capacidade polifacética do propio Castelao. En definitiva, 
a árbore será para Castelao un elemento portador de grande cantidade de significados simbólicos, pois en ela vese reflectida a propia natureza e a capacidade de xerar vida e sustento desta, ademais, os elementos paisaxísticos tamén serán conxugados con outros elementos que poden denotar significados máis complexos. Dentro do Diario de 1921 (Castelao 2000, 5: 221) atópase a figura debuxada dunha árbore, na cal se pode observar un cativo subido encol da póla do que semella ser un piñeiro polo seu toro alongado; asemade, a cortiza rugosa tamén concorda coa da especie vexetal. Por unha parte, o bebé que se asenta pra amarrase ó piñeiro e chuchar dos peitos que nacen da codia da árbore. Do buraco na parte inferior do tronco sae unha serpe; non obstante, a testa desta preséntase descarnada, amosando a súa caveira espida, imprimindo unha sensación máis fatalista á figura serpentina. Aquí o vencello que se amosa entre o elemento humano, representado polo neno, pódese deducir unha relación simbiótica, pois a vida e a morte atópanse reflectidas mediante o devalar, presente no ciclo vital. Por unha parte, o nacemento e a vida son refractados pola figura do neno que mama dos tetos da natura, agromados da árbore; por outra, a morte aparece reflectida a través da figura, tamén natural, da serpe, magnificando o compoñente evocador da morte a través da caveira núa que asexa ó neno. Ó mesturar estes elementos co devalar na paisaxe dedúcese un vencello ineludible entre humano e natura.

Como se ve, a natura fica plasmada a través de diferentes vieiros dentro da obra de Castelao nos cales a significación variará dentro do mensaxe que autor intente trasladar ó seu lectorado. Porén, resulta interesante contemplar o consciente que é Castelao ó incluír con tal centralidade elementos naturais como é o árbore para intentar plasmar a idiosincrasia e a identidade dun pobo, dende a súa esencia ata o seu comportamento e das actividades que definen o seu modo de vida. A xenialidade do autor tamén reside no carácter central que adquire en moitas das súas creacións, pois non é un elemento accesorio senón que, como no caso da árbore no Sempre en Galiza, resulta un elemento central dende o que comezar unha reflexión ou dende onde comezar a construír un texto. Ademais, o respecto co que Castelao trata ás árbores dentro da súa obra non pasa desapercibido, pois outórgalles sentimento ademais dun sentido pragmático que calquera lle outorgaría, como é o caso da produción de madeira. Como xa se dixo a visión do autor sobre a árbore está determinada por un simbolismo concreto, que el asocia coa idiosincrasia galega, coas actividades propias do mesmo pobo e cunha relación san co medio ambiente. 
En canto á visión do animal por parte de Castelao amosarase unha notable empatía pola situación do animal á vez que este se emprega como punto de partida sobre o cal reflexionar. A transferencia de capacidades e características propias do humano ó animal, ou viceversa, ou a alusión ó comportamento mimético dunha especie coas outras, será unha das constantes no referente á inclusión de animais dentro de obras de carácter narrativo. A comparación de comportamentos, intercambiables entre o animal en cuestión e o humano é un recurso relativamente frecuente no eido literario. Non obstante, atopámonos perante un caso no que o comparatismo resultará, unha vez máis, un exercicio que permitirá achegar conclusións a través de similitudes e desemellanzas. Véxanse a continuación as palabras de Greg Garrard (2004: 140) darredor a esta cuestión:

Humans can both be, and be compared to, animals. There is, therefore, an extensive "rhetoric of animality", as Steve Baker calls it, that is as functional in descriptions of human social and political relations as it is in describing actual animals.

Ademais de ser comparados humanos e animais, os animais tamén poden ser interpretados dentro dun marco social e político que lles é alleo, isto é dende un prisma humano segundo afirma Garrard. A sinalada rhetoric of animality achegará a posibilidade de elaborar descricións sobre as relacións sociopolíticas amosadas no seo dunha obra a través das figuras animais. Non obstante, o mesmo autor afirma o seguinte: "The study of the relations between animals and humans in the Humanities is split between consideration of animal rights and cultural analysis of the representation of animal» (Garrard 2004: 136). Esta afirmación representa dúas vías de análise no referente á figura do animal. Por unha banda, a xa sinalada, unha visión simbólica que emana ben da fisionomía do animal, ben da do simbolismo característico asociado ó imaxinario occidental ou ben do simbolismo ${ }^{2}$ que desprende a relación do animal co humano. Pola outra banda, Garrard sinala a consideración dos dereitos animais como outra das vías de análise que poden achegar as humanidades a través dunha visión ecocrítica; non obstante, esta cuestión está directamente relacionada co

2. "Complicated issues arise as Animal Studies balances the central place of other animals' realities with humans' long-standing and vibrant preoccupation with animal-connected symbols. In the past, some scholars have taken the study of symbols employing other animal images of one kind or another to be the major thrust of Animal Studies" (WALDAU 2013: 134). 
antedito "Simbolismo da relación do animal co humano", pois será neste tipo de situacións nas que será precisa a contemplación de determinados dereitos animais. A cuestión dos dereitos animais será abordada polo mesmo Castelao na súa obra tamén dun xeito explícito en moitas das ocasións. Véxase, por exemplo, o seguinte fragmento do Sempre en Galiza, onde Castelao reflexiona sobre a figura da vaca, da súa significación e da percepción popular arredor do animal como xa o fixo no caso da paisaxe. Non obstante, a estruturación do texto será similar ó xa comentado da «albre»; porén, o elemento sobre o cal se medite será outro, e se a árbore se vencellaba directamente coa terra, neste caso, a vaca farao directamente coa humanidade, máis concretamente co pobo galego. Cando se aluda á «nosa vaca» será unha mención directa á "nosa xente»:

\section{A VACA}

A vaca é o símbolo da paz.

Val máis o que siñifica unha vaca que o que simboliza un león rampante. $\mathrm{X}$ a o dixo un dos nosos economistas: "O albre xenealóxico dunha vaca de leite é máis útil que o albre xenealóxico dun aristócrata».

A vaca esqueceuse dos cornos e dános o seu traballo. O seu leite, a súa carne, o seu coiro e a carne e o corio dos seus fillos. [...]

A vaca é o amparo dos probes libres.

Os concursos de vacas leiteiras valen máis que os "concursos de Belleza".

A nosa vaca ten o pesebre en Galiza e os tetos en Madrid. E o que non lle dá de comer a unha vaca non ten dereito a muxila. [...]

Se non fose polo leite das vacas a piolleira das cibdades morreríase desnutrida. A vaca é a ama de cría da Humanidade.

O día que nós emitamos papel-moeda non estamparemos nel o retrato dos políticos, nin dos sabios, nin dos artistas; estamparíamos, somentes, a figura dunha vaca, como símbolo da nosa economía humanamente distribuída.

O día que Galiza sexa unha comunidade cooperativa, ergueremos un gran moimento cunha vaca en bronce dourado.

Tamén hai razas de vacas, e a mellor é a nosa. 
O día que seipamos o que val unha vaca, Galiza quedará redimida (Castelao 2000, 2: 191) $)^{3}$.

O autor comeza o texto cunha sentenza breve e concisa, na cal identifica á vaca como símbolo da paz. Esta visión concorda coa visión tradicional en Occidente, como xa sinala o mesmo Aristóteles $(1992,48)$ na súa Historia de los animales: "También los animales presentan las siguientes diferencias relativas al carácter. En efecto, unos son mansos, indolentes y nada reacios, como el buey». Esta identificación co carácter manso da vaca e do boi vén determinada pola vinculación histórica á especie humana como animal domesticado e de traballo. Non obstante, a que pode ser contemplada como máxima representación do carácter manso do boi é sinalado por Mariño Ferro $(2014,91)$, pois será un animal que acudirá sen oposición ó seu sacrificio, feito que o fai digno de tal fin. Castelao no seguinte fragmento confirma o carácter doméstico da vaca asemade que a identifica como fonte de riqueza, tanto que é máis relevante pra a economía popular estudar a liñaxe dunha vaca que a dun aristócrata. Unha reivindicación pragmática da figura da vaca e da súa rendibilidade. Desta afirmación pode inferirse a visión da vaca como unha compoñente que reflicte a economía real dun pobo, neste caso do galego, perante a oposición co aristócrata, o cal nesta ocasión pode representar unha visión económica afastada da realidade e, presumiblemente, especulativa. Toda esta reflexión, ó igual que as posteriores, gravita darredor da figura da vaca, do mesmo xeito que acontecía anteriormente. No terceiro adaxio, o autor volve facer referencia á mansedume da vaca a través da significación dos seus cornos, porén, tamén se fai alusión a todo aquilo que achega economicamente, pois será coiro, leite e carne. Adoito, a visión máis frecuente encol da vaca na economía pasa polo leite e a carne, emporiso, non se debe esquecer o emprego do coiro, que conta coa característica de non ser un produto de consumo masivo como os dous anteriores e, ademais, está estreitamente vencellado á artesanía e, polo tanto, a un tipo de economía popular. O escritor contraporá a beleza estética ó pragmatismo na frase "Os concursos de vacas leiteiras valen máis que os "concursos de Belleza" ", baseándose novamente nun argumento que remite á unha visión económica de base apegada á realidade dun pobo. Deseguido, atópase unha das celebérrimas frases do autor; a través da vaca, que representará a Galiza, fala das posturas centralistas do goberno ó sinalar que a vaca ten "os tetos en Madrid», mais tamén alude ó pobo galego cando nomea onde «ten o pesebre», deste xeito identifica á sociedade galega como

3. Este texto tamén se atopa presente nos escritos políticos do autor (CASTELAO 2000, 3: 137) baixo o título de «Faíscas». 
o ente que mantén a vaca mais que non desfruta dos seus réditos. Castelao continúa criticando ó centralismo, urbano neste caso, mediante a figura da vaca, a cal asocia cunha economía de carácter rural que, ademais, sustenta a economía das urbes ${ }^{4}$. Por extensión, situará a vaca como «ama de cría da Humanidade", esta asociación ten sentido se vemos que a riqueza que xera o animal está na base máis elemental e de subsistencia da economía galega daquel entón. O autor continúa con outra reflexión de carácter político que fai da vaca símbolo dunha "economía humanamente distribuída" nas súas propias palabras. O texto prosegue con outra referencia á actividade económica vencellada coa vaca. Pra rematar, o autor fai alusión ó valor da vaca, como facía tamén no caso das árbores, o descoñecemento da natura, neste caso do animal volve a converterse na causa das desgrazas do pobo galego, o cal o día que se decate do que vale unha vaca quedará redimido.

A vaca, ademais de servir de metáfora e anáfora sobre a que construír un discurso mantén unha relación medianamente san co humano, pois a convivencia nun tipo de simbiose repara réditos ás dúas especies. A asociación da vaca como elemento básico da economía galega é recorrente no texto comentado; porén, o autor non se esquece da relevante cuestión da relación do humano co animal. No seo do libro Cousas atópase o relato do que se ofrece unha pasaxe, profundamente ilustrativa, na que afonda de forma abondosa nesta cuestión:

Manter un animal para comelo non está ben, aínda que troquémo-la súa carne na nosa propia carne; pero manter con agarimo un animal para levalo dispois á feira, paréceme unha mostra da ruindade humán. [...] O chorar dos cabritos, que se laian coma fidalguiños esmirriados, pode feri-lo peito dun home endeble; o noxente carpir dos porcos, que berran por calquera cousa, abrouxa os nosos ouvidos e desfai toda compasión. Pola rúa van pasando, no remate da feira, os regueiros da dor animal; pero nas feiras hai algo máis. [...] Os homes anda ó seu e non reparan na outra dor, na dor humán que sinten os animales de Deus. As probes vacas endoudecidas que chaman polos fillos, os probes puchos que van ó matadeiro chamando polas nais... (Castelao 2000, 1: 143)

No relato Castelao describe un día de comercio nunha feira de gando, na historia destaca a perspectiva do narrador que focaliza a atención no sufrimento animal xa dende o primeiro parágrafo. Non obstante, o texto continúa centrando a atención na feira e na compoñente humana desta;porén,

4. Quizais sexa pertinente comentar que a metáfora de Castelao non queda só no emprego da vaca como elemento característico, senón que continúa a súa construción metafórica sobre outro animal como son os piollos. 
segundo avanza a focalización vai mudando, achegándose, devagar, á perspectiva animal. Castelao reflexiona sobre o trato que o humano confire ó animal, no final do terceiro parágrafo do texto sinalado, fai referencia ós "regueiros da dor animal", esta sentenza ten un dobre valor significativo, pois aludirá a dous tipos de dor diferenciadas. Por unha parte, a dor máis física, pois noutrora as vacas e os bois debían desprazarse longas distancias sen transporte pra acudir a feira, en consecuencia o autor pode referirse ó sangue dos pés mancados e esfolados dos animais. Por outra, tamén se pode facer unha interpretación metafórica da mesma frase, xa que se podería interpretar que se fai referencia á dor que portan os animais camiñando en ringleira de camiño á feira. Asemade, cómpre identificar unha dobre antropomorfización ${ }^{5}$ que se desprende no texto, por unha parte, o autor atribúe sensibilidades características do humano cando fai referencia á "dor humán que sinten os animais de Deus", pola outra, ó final do texto os animais contan coa facultade da fala, poñendo a verba dos humanos nos beizos dos bovinos. Partindo desta capacidade atribuirá outra indirectamente, pois os bois tamén terán a capacidade de razoar e predicir o seu futuro, sendo conscientes do seu destino. Esta capacidade de empatía por parte do autor confire un cariz ecocrítico á súa obra que transcende o social e o humano, chegando a empregar o animal como metáfora sobre a que construír un discurso pra ilustrar problemas e situacións propias dos humanos, mais sen perder de vista o papel e a situación do propio animal, sempre dende unha perspectiva empática.

\section{CONCLUSIÓN}

Despois de analizar algúns elementos concretos dentro da obra de Castelao, como a paisaxe a través da árbore e os animais a través da vaca, pódese chegar á conclusión de que moitas das súas producións teñen unha elevada carga ecocrítica, ademais de empregar motivos propios da natureza. Pois non só se se atopan algúns destes elementos no seo das súas producións, como a paisaxe ou os diferentes animais que aborda noutros

5. "Anthropomorphism, from the Greek anthropos and morphe meaning 'human' and 'form' respectively, is the attribution of human characteristics to non-human objects, which include both 'other' animals and innate objects. Originally objected to when it pertained to attributing human characteristics to Gods, anthropomorphism has come, in the modern era, to be a dirty word, specifically in scientific discourse» (BODDICE 2012: 266). 
relatos, senón que a fondura con que son abordadas algunhas das temáticas $^{6}$ fan deducir que non se tratan de casos illados ou anecdóticos. Castelao aborda temas ecocríticos na práctica totalidade das súas obras, sexa cal for o medio de expresión: literatura ou calquera outro arte. O autor non prescindirá da crítica ó humano e ó enxalzamento da natura como se puido comprobar nas anteriores seccións. Emporiso, tamén se poden identificar algúns patróns no emprego de motivos ecocríticos.

Un destes patróns é o uso de elementos cun claro carácter ecocrítico no comezo dalgúns dos seus relatos pra tentar dar veracidade a través da enunciación de detalles; este recurso, que encomeza presentando unha paraxe ou situación a través de multitude de compoñentes naturais é frecuente na súa narrativa, especialmente no seu libro de Cousas. Esta característica tamén se dá en obras adscritas a outras categorías, como é o caso da dramaturxia c'Os vellos non deben namorarse, onde antes de comezar a acción se achegan detalles sobre o escenario onde se desenvolverá a acción. A principal motivación que pode levar a Castelao a empregar esta estratexia reside na súa visión simbólica da natura. Mais, como xa se comentou nas páxinas anteriores trátase dunha natura concreta, paisaxe e fauna da Galiza. O autor identificará a natura galega no seu conxunto como expresión do pobo galego. Por unha parte, a paisaxe é un claro conformador do carácter e do espírito galego dende as teses do mesmo de Castelao e doutros coetáneos como Otero Pedrayo. Pola outra, os animais, como é o caso da vaca, determinarán en gran parte o modus vivendi do pobo. Ámbolos dous factores, canda un terceiro que sería o idioma, representarán pra o autor fontes das cales emana o Volkgeist galego. As dúas nocións, paisaxe e fauna, están intimamente ligadas a unha etnoloxía determinada. Polo tanto, estes elementos ecocríticos compren unha dobre función, en primeiro lugar, dar verosimilitude á ficción narrada como sucede adoito mais, en segundo lugar, localiza ó relato nunha esfera determinada -a galega- a través dun elemento concreto: a natureza.

O vencello que atinxe á natura, á paisaxe, á vexetación, ós animais e ó pobo galego, destaca pola fondura que o autor adica á súa descrición e tratamento, ademais da cadencia coa que aparecen motivos ecocríticos no seo das súas creacións tamén destaca o enfoque das súas obras, que se afasta do antropocentrismo. Inclusive en moitas ocasións, como acontece notablemente en Cousas da vida; animais, empregará unha perspectiva que parte dende o animal pra tratar asuntos de índole social ou puramente

6. A meirande parte ven determinadas pola relación que o humano desenvolve co medio, transducido á paisaxe, e co animal. 
humanísticos. Non obstante, a perspectiva empregada toma ó animal como punto de partida e non ó humano. En moitas ilustracións de Castelao a compoñente humana non terá presenza algunha, deixando todo o papel protagonista á natura. A presenza dos motivos susceptibles de ser contemplados como ecocríticos son tan abondosos no conxunto das súas obras que é difícil imaxinar un Castelao sen a conciencia ecolóxica que se tentou amosar a través dos exemplos expostos. Asemade, non resulta estraño identificar unha posición do autor en clara defensa da natura, pois ó longo das súas creacións amosará unha clara empatía cos desposuídos, sexan nenos, mulleres ou animais, inclusive a mesma terra. O creador manifestará a súa disposición a prol dos desfavorecidos ó longo das súas creacións; no caso da natura non será distinto, especialmente no caso dos animais. Probablemente a preferencia pola reivindicación de certos dereitos animais veña determinada por seren entes biolóxicos con comportamentos semellantes ó humano. Emporiso, Castelao non renega dunha defensa da natura dun xeito máis abstracto e global, así se pode comprobar na figura do fauno, presente no Diario de 1921 (Castelao 2000, 5: 122).

A figura do "fauno" aparece debuxada chuchando nun seo que emerxe da terra, no medio dunha fraga mesta na que penetran as raiolas de sol. A figura do fauno, metade humano e metade animal fica amarrando a un dos peitos que se poden ver agromar no chan da foresta. Non obstante, a personaxe do cadro pode contar con connotacións negativas, pois nas súas Estampas da guerra a figura do fauno é identificada co fascismo nunha ilustración de xeito moi claro. Pódese interpretar, pois, que este cadro é unha reivindicación crítica da sobreexplotación da natura por parte do humano, unha crítica velada pola metáfora da relación da peor versión do humano, personificada no fauno, coa natura na súa dimensión máis abstracta. Pódese concluír que a preocupación medioambiental fica presente no legado de Castelao a través da temática de multitude das súas creacións. A vertente ecocrítica do rianxeiro acompaña outras facetas que lle son propias como a de denuncia social, buscando sempre unha xustiza que se lembre dos esquecidos e dos marxinados.

Ademais dos elementos analizados existen moitos outros que son susceptibles de seren analizados baixo unha perspectiva ecocrítica, os cales están presentes na meirande parte das súas creacións, sexa cal for o medio de expresión. É difícil atopar unha creación do autor que non conte con

7. No plano máis social o autor amosará a súa posición en contra de figuras de poder como son caciques, políticos ou empresarios e a prol de labregos mariñeiros e xente dunha clase social baixa. 
elementos simbólicos representativos da natura. A través das súas creacións o autor amosa unha abraiante conciencia ecocrítica pra o seu tempo, quizabes por mor dunha visión conservadora que parta da oposición rural/urbano. Non obstante, a profundidade coa que aborda determinados temas, amais do modo de facelo, denota unha clara conciencia ecolóxica. Castelao semellaba consciente dos problemas medioambientais que xeraba un sistema capitalista nun medio determinado. Algúns dos asuntos tratados polo autor, como a sobreexplotación pesqueira ${ }^{8}$, forman parte das problemáticas que denuncian grupos ecoloxistas hoxe en día. Ó contemplar a totalidade da súa obra pódese deducir que Castelao tenta achegar certo didactismo, advertindo ó lectorado de diferentes inxustizas de índole ecolóxica, como pode ser o maltratado animal ou destrución natural que supón un modo de vida urbano. Asemade, o enfoque afastado do antropocentrismo e mesmo crítico coa figura do humano posibilita a consideración dun enfoque completamente ecocrítico.

Como consideración final, pódese afirmar que a carón dun Castelao que é coñecido como político, escritor, pintor e artista tamén se atopa un Castelao que resulta ser un ecoloxista senlleiro noutrora, pois o seu pensamento, no que atangue á natura, fica adiantado ó seu tempo. Secasí, a fondura dos seus pensamentos, das súas reflexións, conta con vixencia arestora. Esta nova lectura da súa obra pode considerarse unha boa proba da grandeza do legado que o mártir do exilio deixou a tódolos galegos, pois segue engadindo valor ás letras e artes cada vez que é observado dende unha perspectiva diferente, a cal achega novas conclusións e non fai máis que denotar as múltiples perspectivas das que Castelao era consciente cando creaba.

\section{REFERENCIAS}

ARISTÓTELES. 1992. Investigación sobre los animales. Traducido por Julio Pallí Bonet. Madrid: Gredos.

BodDICE, Rob. 2012. Anthropocentrism: Human, Animals, Enviroments. Leiden: Brill.

BuelL, Lawrence. 1995. The Environmental Imagination. Cambridge, Mass.: Harvard University Press.

8. Véxase o relato "dos apóstolos» de Cousas (CASTelao 2000, 1: 115): «As sardiñas volverían se os gobernos quixesen». 
Castelao, Alfonso Daniel R. 2000. Obras. Editado por Henrique Monteagudo Romero. 5 vols. Vigo: Galaxia.

GARRARD, Greg. 2004. Ecocriticism. Londres: Routledge.

GIFFORD, Terry. 2009. "A ecocrítica na mira da crítica atual». Traducido por Izabel Brandão. Terceira margem 20 (xaneiro-xullo 2009): 244-261.

GLOTFLELTY, Cheryll. 1996. "Introduction. Literary Studies in an Age of Environmental Crisis". En The Ecocriticism Reader: Landmarks in Literary Ecology, editado por Cheryll Glotfelty e Harold Fromm, xv-xxxvii. Athens: The University of Georgia Press.

GLOTFLELTY, Cheryll. 2010. "Los estudios literarios en la era de la crisis medioambiental». Traducido por Diana Villanueva Romero. En Ecocríticas. Literatura $y$ medio ambiente, editado por Carmen Flys Junquera, José Manuel Marrero Henríquez e Julia Barella Vigal, 49-65. Madrid: Iberoamericana.

LIDDELL, Henry George e Robert SCOTT. 1882. Greek-English Lexicon. Washington: Harper and Brothers.

MariÑo Ferro, Xosé Ramón. 2014. Diccionario del simbolismo animal. Madrid: Encuentro.

Otero Pedrayo, Ramón. 1955. Paisaxe e cultura: Ensaios. Vigo: Galaxia.

PONDAl ABENTE, Eduardo. 1995. Queixumes dos pinos e outros poemas. Editado por Xavier Senín. Vigo: Galaxia.

Waldau, Paul. 2013. Animal Studies: An Introduction. Nova York: Oxford University Press. 
